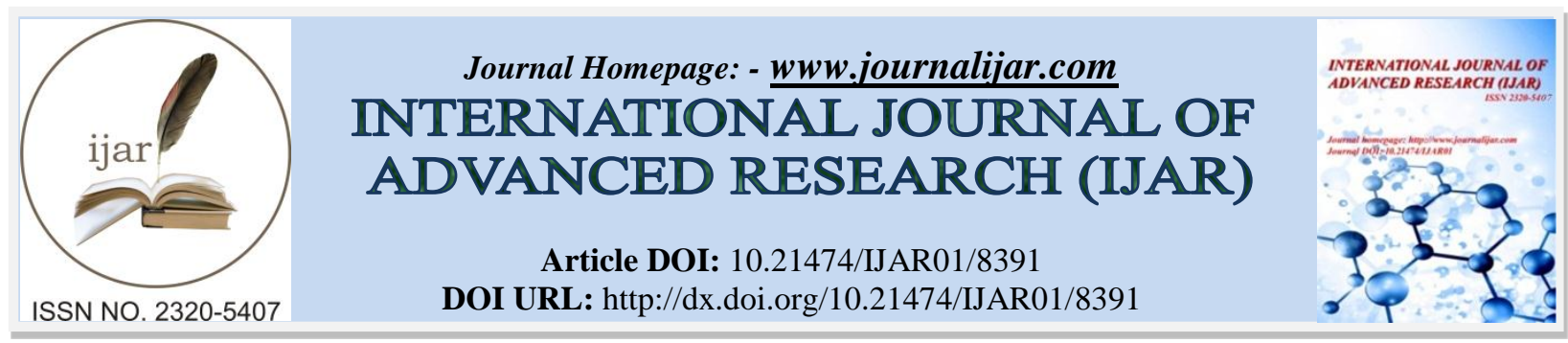

RESEARCH ARTICLE

\title{
DETERMINATION OF SERUM MATRIX METALLOPROTEINASE 2 AND 9 (MMP-2) (MMP-9) IN BREAST CANCER INVASION AND METASTASIS.
}

\author{
Rawan Hamid Jarrah ${ }^{1}$, Dhamia Kasim Suker ${ }^{2}$, Khairallah AS Mohammed ${ }^{1}$ and Rafid Adel Abood ${ }^{3}$. \\ 1. Department of Medical Lab Technology, Health and Medical Technology College, Southern Technical \\ University. Basrah, Iraq. \\ 2. Department of Biology, College of Science, Basrah University. \\ 3. Medical College, Basrah University.
}

\section{Manuscript Info}

Manuscript History

Received: 12 November 2018

Final Accepted: 14 December 2018

Published: January 2019

Key words:-

Matrix metalloproteinase, ECM, Breast cancer.

\begin{abstract}
Breast cancer is the most frequently diagnosed cancer and the leading cause of cancer death among women worldwide. Matrix metalloproteinases (MMPs) are a family of enzymes implicated in the degradation and remodeling of extracellular matrix and in vascularization. The current study, was aimed to determine the effect of gelatinizes in breast cancer progression by the measurement the levels of MMP-2 and MMP-9 in serum of breast tumor by ELISA. The present study involved 80 samples including 60 patients of breast tumor, which were selected from Medical Centre for Oncology, and 20 as control (normal subject), which select from southern technical university from south region of Iraq in Basrah city during the period from October 2017 to February 2018. The results showed that measurements of MMP-2 and MMP-9 in the serum of the women with malignant tumor were highly significant $(\mathrm{P} \leq 0.01)$ compared with benign and control, regarding the grade of cancer subjects, stage and lymph node metastasis. This conclude the present of a correlation of the serological measurement of MMP-2 and MMP-9 in patients with breast cancer and metastasis.
\end{abstract}

Copy Right, IJAR, 2018, .All rights reserved.

\section{Introduction:-}

Cancer is one of the major reasons of death-rate all over the world [1]. Thus, various data was generated as result of biomedical scholar articles and papers on molecular actions that are interacted during the formation phases of cancer and detecting passages that lead to cancer development [2]. Breast cancer prevails in several ways. It can move direct into the skin and muscle, through lymphatic's vessels and other lymph nodes and through the blood stream to lungs, bone, liver, and brain [3]. The extracellular matrix (ECM) play assist role as an intermediate for cell-to-cell linkages and can move carry signal cells via cell surface ECM receptors such as integrins [2]. For more than 40 years, researches are conducted and revealed an increasing evidence showing that extracellular matrix remodeling proteinases, such as matrix metalloproteinases (MMPs), are the basic intermediaries of the modifications observed in the microenvironment while cancer is developing [2-4]. MMPs are part of a zinc-dependent family of endopeptidases associated in a variety of physiological procedures, including wound healing, uterine involution and organogenesis as well as in pathological conditions, such as inflammation, vascular and auto-immune disorders, and

Corresponding Author:-Rawan Hamid Jarrah.

Address:-Department of Medical Lab Technology, Health and Medical Technology College, Southern Technical University. Basrah, Iraq. 
carcinogenesis [4-5]. MMPs have been reflected as anticipated diagnostic and predictive biomarkers in several kinds and phases of cancer [6].

The matrix metalloproteinases (MMPs) are a family of zinc dependent endopeptidases [7]. There are approximately 28 MMPs associated in breast cancer development and progression [8] . They are combined both by tumor and peritumoral stromal cells [9], and their main function is destruction of proteins in the ECM [10]. They can be considered as the most significant proteolytic enzyme for connective tissue dissolution. MMPs are indicated in cancer invasion and metastasis with various classes of MMPs being associated often with cancers of varying origin [11].

\section{MMPs in Breast Cancer}

Breast cancer is the most frequently diagnosed cancer, with 1.67 million cases worldwide and the leading cause of cancer death among women, accounting for $25.2 \%$ of the total cancer cases and $14.7 \%$ of the cancer deaths [12-13]. Its incidence is higher in developed countries than in non-developing countries due to variation in risk exposure and to better detection methods [14]. Available evidence in Basrah suggests that breast cancer is increasing at a significant skip in recent years [15-16]. For example, a hospital-based study reported an incidence rate of about 11/ 100,000 females [17], but recent reports put the annual incidence rate among females at around 23 per 100,000 [18].

Degradation of the extracellular matrix is an essential process allowing tumor cells to invade local tissue and blood vessels and move to new metastatic location. Tumor cells secrete specific proteinases; known as serine proteinases, aspartate proteinases, cysteine proteinases and matrix metalloproteinases that primarily influence tumor invasion and metastasis [19-20].

Among several MMPs that are involved in breast cancer progression, Gelatinase-A (MMP-2) and Gelatinase-B (MMP-9) are thought to be of key importance: MMP-2 is expressed in a very early stage breast cancer and is believed to contribute to the first events leading to tumor formation [21]. It is largely absent in normal adult breast tissue but it is expressed in some benign tumors such as fibroadenomas [22]. Its expression becomes more consistent with increasing tumor grade and MMP-2 immunoreactivity has recently been found to be an independent predictor of decreased survival of breast cancer patients [23-24]. 1996. MMP-9 is one of the two gelatinases that has been implicated in tumor cell invasion and metastasis because of its unique ability to degrade Type IV collagen (a major component of the basement membrane) and other essential extra-cellular matrix components $(8,9)$. MMP-9 and its natural inhibitor, tissue inhibitor of metalloproteinase-1 (TIMP-1), may be involved in early cancer development and progression; elevated serum10-13 and tissue 14, 15 levels of both enzymes have been found in cancer patients.

\section{Materials and methods:-}

1. The study involved 40 breast cancers as well as 20 benign tumors from women admitted to AL-Sader Hospital and 20 healthy women in Basrah, Iraq between 2017 and 2018. All patients with breast cancer recruited in this study were diagnosed as stages II-III. The age of patients was range between 25 to 82 years.

2. Peripheral blood samples were collected by gel tube and centrifuged at $4,000 \mathrm{rpm}$ for $15 \mathrm{~min}$ at $4^{\circ} \mathrm{C}$.to determine the concentration of MMP-2 and MMP-9 by ELISA (cloude-clone. USA).

\section{Statistical analysis:-}

Statistical package for social science (SPSS) was used to analyze the data. Chi-square (X2) test, T-test and anova, mean value were used to assess the significance of differences between groups. P. value less than 0.05 was applied as statistically significant and $\mathrm{p}$. value less than 0.01 considered as highly significant.

\section{Results:-}

The concentration of MMP2 and MMP9 that investigated by mean of ELIZA technique, using blood obtained from cancer patients, benign tumor and healthy control subjects, revealed that both MMP-2 and MMP-9 exhibited a significant increase $(\mathrm{P} \leq 0.01)$ comparing with the control group (Table 1-1).

Table 1.1:-Comparison of mean values for MMP2 \& MMP9 in serum of malignant, benign and control group.

\begin{tabular}{|c|c|c|c|c|}
\hline \multirow{4}{*}{$\begin{array}{l}\text { Enzyme } \\
\text { level } \\
(\mathrm{Pg} / \mathrm{mL})\end{array}$} & \multicolumn{3}{|c|}{ STUDY GROUPS } & \multirow{4}{*}{ P. value } \\
\hline & \multirow{3}{*}{$\begin{array}{l}\text { Control } \\
\text { Mean } \pm \text { SD } \\
\mathrm{N}=20\end{array}$} & \multicolumn{2}{|c|}{ Breast Tumor } & \\
\hline & & $\begin{array}{l}\text { Malignant } \\
\mathrm{N}=40\end{array}$ & $\begin{array}{l}\text { Benign } \\
\mathrm{N}=20\end{array}$ & \\
\hline & & Mean $\pm S$ & & \\
\hline
\end{tabular}




\begin{tabular}{|l|l|l|l|l|}
\hline MMP2 & $.4785^{\mathrm{c}} \pm .0762$ & $1.481^{\mathrm{a}} \pm .0981$ & $.6687^{\mathrm{b}} \pm .1377$ & $\begin{array}{l}0.001 \\
(0.11)\end{array}$ \\
\hline MMP9 & $1.118^{\mathrm{c}} \pm .1974$ & $2.561^{\mathrm{a}} \pm .2893$ & $1.720^{\mathrm{b}} \pm .1707$ & 0.000 \\
& & & & $0.17)$ \\
\hline
\end{tabular}

a, b, c mean with different subscripts differ significantly at 0.05

On the other hand, the level of the enzymes that revealed according to thegrades, showed that the concentration for both enzymes elevated in both grades II and III, by the mean of statistical analysis the enzyme was highly significant in grade II and III comparing with grade I (Table 1-2).

Table 1.2:- Correlation between grades and the expression of the MMP2 and MMP9in the patients of breast cancer.

\begin{tabular}{|c|l|l|l|l|}
\hline Enzymes & Grade & $\begin{array}{l}\text { Patients with breast } \\
\text { cancer } \\
\text { N }\end{array}$ & Mean \pm S.D & $\begin{array}{l}\text { P. value } \\
\text { (RLSD) }\end{array}$ \\
\hline \multirow{5}{*}{ MMP2 } & I & 2 & $1.423 \pm .3860^{\mathrm{c}}$ & 0.00 \\
\cline { 2 - 4 } & II & 32 & $3.186 \pm .7129^{\mathrm{a}}$ & \\
\cline { 2 - 4 } & III & 6 & $1.747 \pm .9413^{\mathrm{b}}$ & 0.00 \\
& MMP9 & I & 2 & $1.333 \pm .3075^{\mathrm{c}}$ \\
\cline { 2 - 4 } & II & 32 & $3.275 \pm .4550^{\mathrm{a}}$ & \\
\cline { 2 - 4 } & III & 6 & $2.152 \pm .8258^{\mathrm{b}}$ & \\
\hline
\end{tabular}

a, b,c mean with different subscripts differ significantly at 0.01 .

In order to investigate whether the enzymes were effects by the stages of the disease, both enzymes were measured according to the stage of the disease. The result showed marked increase in both enzymes during stage II and III, then the enzymes seems to decline during stage IV (Table 1-3).

Table 1.3:-Correlation between stage and expression of the MMP2 and MMP9 in the patients with breast cancer.

\begin{tabular}{|c|c|c|c|c|}
\hline Enzymes & Stage & $\begin{array}{l}\text { Patients with breast } \\
\text { cancer } \\
\text { N. }\end{array}$ & Mean \pm S.D & $\begin{array}{l}\text { P. value } \\
\text { (RLSD) }\end{array}$ \\
\hline \multirow{4}{*}{ MMP2 } & I & 0 & 0 & \multirow{4}{*}{$\begin{array}{l}0.00 \\
(0.32)\end{array}$} \\
\hline & II & 23 & $3.043 \pm .9902^{\mathrm{a}}$ & \\
\hline & III & 14 & $2.931 \pm .6955^{\mathrm{a}}$ & \\
\hline & IV & 3 & $1.416 \pm .4099^{b}$ & \\
\hline \multirow{4}{*}{ MMP9 } & I & 0 & 0 & \multirow{4}{*}{$\begin{array}{l}0.00 \\
(0.30)\end{array}$} \\
\hline & II & 23 & $3.029 \pm .5537^{\mathrm{a}}$ & \\
\hline & III & 14 & $2.967 \pm .8982^{\mathrm{a}}$ & \\
\hline & IV & 3 & $1.577 \pm .2273^{b}$ & \\
\hline
\end{tabular}

a,b, mean with different subscripts differ significantly at 0.01 .

Since the enzymes promotes primary tumor growth leading to increase metastasis. A comparison was carried out between metastatic and non-metastatic samples, and statistical analysis revealed there were a significant difference $(\mathrm{P} \leq 0.01)$ in metastatic samples comparing with non-metastatic for both enzymes (Table 1-4).

Table 1.4:- Levels of MMP2 and MMP9 enzymes in the serum of metastatic and non-metastatic cancer

\begin{tabular}{|l|l|l|l|}
\hline \multirow{2}{*}{ Enzymes } & \multicolumn{2}{|l|}{ Patient with malignant breast Tumor } & \multirow{2}{*}{ P. Value } \\
\cline { 2 - 3 } & $\begin{array}{l}\text { Metastasis } \\
\text { N. }\end{array}$ & $\begin{array}{l}\text { No metastasis } \\
\text { N. }\end{array}$ & \multirow{2}{*}{0.00} \\
\hline MMP2 & 32 & 8 & \\
Mean \pm S.D & $3.269 \pm .5988$ & $2.381 \pm 1.0863$ & 0.01 \\
\hline MMP9 & 32 & 8 & $2.737 \pm .9475$ \\
Mean \pm S.D & $3.265 \pm .502009$ & & \\
\hline
\end{tabular}


\begin{tabular}{|l|l|l|l|}
\hline & & & \\
\hline
\end{tabular}

\section{Disscussion:-}

Matrix metalloproteinase have been implicated in cancer for more than over years, the MMP-mediated ECM degradation leads to cancer cell invasion and metastasis has been a regulatory source in MMP research, [25]. Gelatinase that degrade the major component of ECM gelatin IV act a crucial role in breast cancer. Gelatinase are important in breast cancer invasion and metastasis [26].

The present study showed overexpression of MMP2 and MMP9 in serum of both malignant and benign tumor in Basrah women comparison with control, but the expression in malignant more than that in benign. The serum level of MMP2 was highly elevated in serum of breast tumor than MMP9 as demonstrated by other study, which showed a statistically significant difference in MMP-2 and MMP-9 levels between the breast cancer and benign breast tumor patient group [27].

According to the grade and stages data showed high expression of both gelatenase in poor differentiated breast tumor (grade III \& II) but low expression in grade (I) as demonstrated by other study, which reported that highly expressed in grade II-III breast cancer tissues as compared to that in the benign breast tumors [28], They concluded that high invasion and malignant activity resulting from the overexpression of MMPs [29]. In stage (II \& III) data showed high level of MMP-2 and MMP-9, but in patient's serum with stage (II) more than in stage (III), while expression of MMP-2 was more elevated than MMP-9. Other study reported that no correlation between both gelatinases and established prognostic factors for breast cancer, such as tumor size, histologic grade, nuclear grade, tumor staging [27].

The current study showed high expression in the levels of MMP2 and MMP9 with positive lymph node metastasis as compared to negative lymph node metastasis patients indicating that MMP2 and MMP9 participate in tumor cells spread and metastasis. Other study [28] showed that MMP2 and MMP9 expression levels were significantly higher in women with positive lymph node metastasis as compared to negative lymph node metastasis patients indicating that MMP2 and MMP9 participate in tumor cells spread and metastasis. In addition further study showed that the activities of latent and active forms of MMP2 and MMP9 in patients with positive lymph node metastasis were higher than patients with negative lymph node metastasis [29]. The study conclude that the increased of MMP-2 and MMP-9 in both serum. High expression of both enzymes correlated with stage II, III. Expression of both enzymes correlated with grade II, II and increased level of the MMP-2 and MMP-9 in lymph node metastasis comparing with non-lymph node metastasis.

\section{References:-}

1. Jemal A, Tiwari RC, Murray T, Ghafoor A, Samueis A, Ward E, Feuer EJ \& Thum MJ (2004). Cancer statistics. CA Cancer J Clin 54, 9-29.

2. Kessenbrock K, Plaks V \& Werb Z (2010). Matrix metalloproteinases: regulators of the tumor microenviroment. Cell 141, 52-67.

3. R. A. Walker, "Breast," in General and Systemic Pathology, J. C. E. Underwood, Ed., pp. 467-492, Churchill Livingstone, 4th edition, 2005.

4. Page-McCaw A, Ewald AJ \& Werb Z (2007). Matrix metalloproteinases and the regulation of tissue remodelling. Nat Rev Mol Cell Biol 8, 221-233.

5. Nagase H, Visse R \& Murphy G (2006). Structure and function of matrix metalloproteinases and TIMPs. Cardiovasc Res 69, 562-573.

6. Roy R, Yang J \& Moses AM (2009). Matrix Metalloproteinases as novel biomarkers and potential therapeutic targets in human cancer. J Clin Oncol 27, 5287-5297.

7. X. Xu, Y. Wang, Z. Chen, M. D. Sternlicht, M. Hidalgo, and B. Steffensen, "Matrix metalloproteinase-2 contributes to cancer cell migration on collagen," Cancer Research, vol. 65, no. 1, pp. 130-136, 2005.

8. A. Kohrmann, U. Kammerer, M. Kapp, J. Dietl, and J. Anacker (2009). ". "Expression of matrix metalloproteinases (MMPs) in primary human breast cancer and breast cancer cell lines: new findings and review of the literature," BMC Cancer, vol. 9, article 188.

9. A. Lebeau, A. G. Nerlich, U. Sauer, R. Lichtinghagen, and U. Lohrs (1999). "Tissue distribution of major matrix metalloproteinases " and their transcripts in human breast carcinomas," Anticancer Research, vol. 19, no. 5, pp. 4257-4264. 
10. M. J. Duffy, T. M. Maguire, A. Hill, E. McDermott, and N. O’Higgins (2000). "Metalloproteinases: role in breast carcinogenesis, invasion and metastasis," Breast Cancer Research, vol. 2, no. 4, pp. $252-257$.

11. T. Shiomi and Y. Okada, "MT1-MMP and MMP-7 (2003). in invasion and metastasis of human cancers," Cancer and Metastasis Reviews, vol. 22, no. 2-3, pp. 145-152.

12. Ferlay J, Soerjomataram I, Dikshit R, Eser S, Mathers C, et al. (2015) Cancer Incidence and mortality Worldwide: Sources, methods and major patterns in GLOBOCAN 2012. Int J Cancer 136: E359-E386.

13. Ferlay J, Soerjomataram I, Ervik M, et al. GLOBOCAN (2012) Cancer incidence and mortality worldwide: IARC, Lyon, France. International Agency for Research on Cancer;

14. Habib OS, Al-Ali JK, Al-Wiswasi MK, et al (2007). Cancer Registration in Basrah 2005. Preliminary results. Asian Pac J Cancer Prev, 8, 187-90

15. BCRG. Cancer in Basrah: Epidemiological analysis of incident cancer 2005-2008.Basrah Cancer Research Group. Dar Al-Kutub for Publication, 2009.

16. Al-Badri K, Ajeel NA (1998). Study of the risk factor of female breast cancer in Basrah Governorate. Med J Basrah, 16, 21-38.

17. Habib OS, Al-Diab JMA, Mohsin A, et al (2010). Experience and outcome of population-based cancer registration in Basrah-Southern Iraq in four years (2005-2008). Asian Pac J Cancer Prev, 11, 51-4

18. Chen, Y. Breast Cancer. http://www.nlm.nih.gov/medlineplus/ ency/article/000913.htm 2012.

19. Stamenkovic I: Matrix metalloproteinases in tumor invasion and metastasis. Semin Cancer Biol 10: 415-433, 2000.

20. Liotta LA, Stetler-Stevenson WG (1991) Tumor invasion and metastasis: an imbalance of positive and negative regulation. Cancer Res 51: 5054s-5059s.

21. Stetler-Stevenson WG: Dynamics of matrix turnover during pathologic remodeling of the extracellular matrix. Am J Pathol 148: 1345-1350, 1996

22. Remacle AG, Noel A, Duggan C, McDermott E, O'Higgins N, Foidart JM, Duffy MJ: Assay of matrix metalloproteinases types 1, 2, 3 and 9 in breast cancer. Br J Cancer 77(6): 926- 931, 1998Google Scholar

23. Heppner KJ, Matrisian LM, Jensen RA, Rodgers WH: Expression of most matrix metalloproteinase family members in breast cancer represents a tumor-induced host response. Am J Pathol 149(1): 273-282, 1996

24. Basset P, Bellocq JP, Anglard P, Chenard MP, Lefebvre O, Noel A, Okada A, Rouyer N, Santavicca M, Stoll I, Wolf C, Rio MC: Stromelysin-3 and other stromelysins in breast cancer: importance of epithelial-stromal interactions during tumor progression. Breast Cancer Res Treat 83: 353-367, 1996.

25. Ranuncolo SM, Armanasco E, Cresta C, Bal De Kier Joffe E and Puricelli L: Plasma MMP-9 (92 kDa-MMP) activity is useful in the follow-up and in the assessment of prognosis in breast cancer patients. Int J Cancer 106: 745-751, 2003.

26. Huhtala P, Chow LT, Eyggvason K. Structure of the human type IV collagenase gene. J Biol Chem 1990; 265:11077.

27. Heo, D. S.; Choi, H.; Yeom, M. Y.; Joo. B.; Jeong Oh, S. S. (2014). Serum levels of matrix metalloproteinase-9 predict lymph node metastasis in breast cancer patients. 1567-1572.

28. Noah, A. M.; Rajaa, M. F.; Nahi, Y. Y.; Mohamed, E. M. (2015). Matrix Metalloproteinases MMP2 and MMP9 Expression in Stages II-III Breast Cancer in Iraqi Women .2449-1810.

29. Sandra, R.; Gordana, K.; Vladimir, J.; Katarina, K.; Marina, N.; Kristina, G. (2013). Values of MMP2 and MMP9 in tumor tissues of basil-like breast cancer patients. Cell. Biochem. Biophys. 68 (1):143-152. 